体力科学 (1999) 48, 519 526

\title{
【教育講座】
}

\section{バーチャルリアリティ技術の医学応用 MEDICAL APPLICATION OF VIRTUAL REALITY TECHNIQUE}

東京慈恵会医科大学 総合医科学研究センター 高次元医用画像工学研究所 服部麻木・高津 光洋・鈴木直樹

\section{I . は じめに}

近年のコンピュータ関連技術の発達により, コ ンピュータグラフィクスは急速に進歩し，個人向 けのコンピュータにおいてもリアリティのある画 像を短時間で作製することが可能になってきた。 このようなコンピュータグラフィクスの進歩に 伴って,コンピュータ内に仮想環境を構築して人 に提示し, 視覚, 触覚, 聴覚を用いて, その環境 下の現象をリアルタイムに知覚させ, インタラク ティブに反応，操作することができるVirtual Reality（VR）技術が開発されてきた。VR 技術は， 産業機器の設計や試作を始め, アミューズメント, 教育等, 様々な分野での応用がなされている。 ま た,ここ数年では医学領域においてもVRの応 用は大きな発展を見せてきた. 特に医学領域では, 医用画像デー夕を用いて画像診断支援, 手術支援, 医学教育と幅広い研究例が数多く見られるように なってきた。

\section{II. 医学用 Virtual reality}

医療分野におけるVR 技術の応用は, 応用領 域に沿って大別すると術前, 術中, 術後での応用, ならびに医学教育の支援などに分けられる，術前 での応用としては, 画像診断支援, 手術シミュレー ションが挙げられる。画像診断支援は, 近年多く なってきた医用画像情報をより直感的に, 素早く 理解させるためのシステムである. 従来の医用画 像は, フィルムや CRT 上で本来は三次元の構造 を持つ情報を二次元的なものとして観察するしか なかったしかし，VR 技術を応用することによ り, 三次元構造は三次元的なものとしてそのまま 直感的に理解できるだけでなく，患者の身体の構
造を実世界で実物を動かすのと同じように触感を 感じながら行うこともできるようになるはずであ る。図 1 にVR 技術を画像診断支援に応用した 場合のイメージ図を示す。図は，医師がヘッドマ ウントディスプレイ (HMD) とデータグローブを 装着し，患者より得られたデー夕から再構築され た心臓の三次元像を基に心蔵内部の様子を観察し ている．当然のことながら，実際には三次元画像 はHMD 内に投影されており，この図のようには 見えないが，VR のイメージを伝えるために写真 上に合成表示して示した。

手術シミュレーションシステムは, 術前に取得 した患者のデー夕を用いて，コンピュー夕上で手 術を行えるシステムである，患者ごとに何度でも 試行が可能なため，患者に適したより良い手術計 画を決定することが可能になる。また，医学生へ の手術教育にも有効であると考える。術中の応用 例としては，data fusion システムや augmented reality を用いた術中支援システムが挙げられる.

ここでいう data fusion とは，術者の視野にある 実像にコンピュータで構築した画像データを合成 表示し, 目標とする葴器, 腫瘍や血管を患者の体 表面上から透視しているかのように提示する技術 である。これにより，患者の体内内部構造を切開 する前から把握することが可能になり，かつ手術 中も術野の内部を見ながら手術することが可能と なる. augmented reality とは, 仮想空間上での 情報を増幅(透過像の表示, 病変部の色を強調, 凹凸を強調など)して使用者の感覚を補助, 増強 するものである。

これらの医用 VR 技術を用いることで，より 安全な手術を短時間で行うことが可能になると考 える．術後での応用としては，歩行訓練等のリハ 


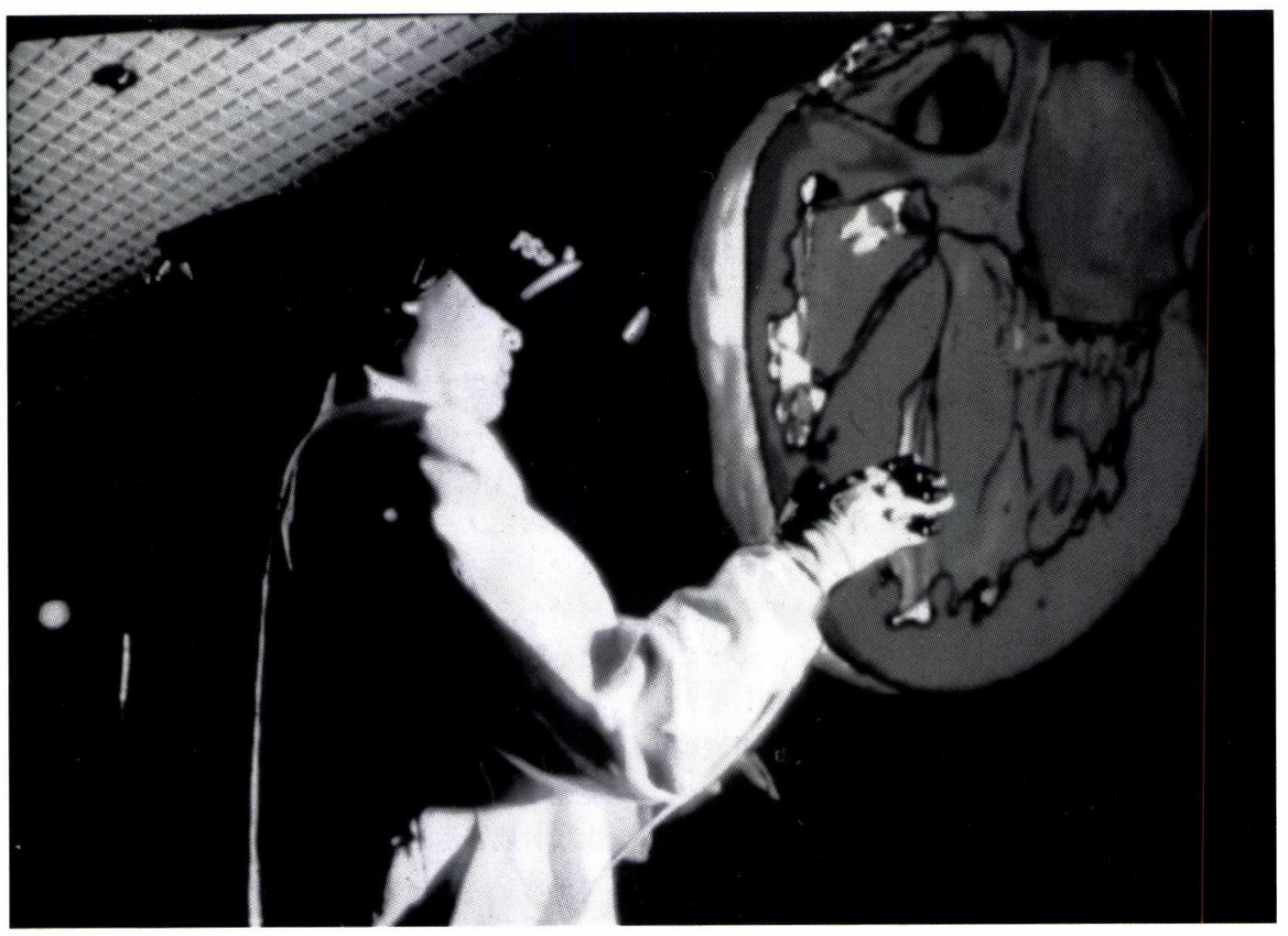

図 1.Virtual Reality 技術を用いた画像診断のイメージ図

ビリテーションをサポートするシステムなどがあ る。また, 術後ではないが, 障害者の活動をサポー トするシステムの開発なども医用 VR 技術の応 用として行われている.

これらの医療におけるVR 技術について，我々 の研究所での研究を具体的な例として取り上げ, 本稿を進めていくことにする.

\section{III. 術中支援システム}

今までの医用画像デー夕は, 医用画像機器に よって生体から計測して画像処理を行った後, ディスプレイ上の観察およびマウスなどのデバイ スによる操作をすることしかできなかった．しか し，VR 技術を用いることによって，この画像デー 夕を観察者の頭脳内で変更することなく, 直感で 内容を知ることができる実体に近いものとして扱 うことが可能になってきた。また，VR 技術は皮 膚や臓器を透過して内部の血管や神経組織を同時
に提示する (data fusion) といった人間の能力を増 強させることができる。 Data fusion 技術を用い た手術を例に挙げると, 術中に種々の手法を用い てリアルタイムに患者の体内の三次元データを取 得して三次元形状の再構築を行い, この三次元像 を術者の視野に合成して提示することが可能であ る.この結果, 術野直下の血管や神経束等, 術中 に注意を要する組織を術野中で確認しながら目標 部位へ到達することができ, 周囲組織の損傷を最 小限にとどめ, 作業時間の短縮が可能になる。 こ のことは, 患者の存命率の向上や予後の回復期間 の短縮に貢献できるはずである.

ここで，一例として超音波を用いた術中支援シ ステムの試作例 ${ }^{1)}$ について述べる。このシステム では対象部位の内部構造と表面形状のリアルタイ ムデータ取得に, 複数の無侵襲的計測法を用いて 行っている.内部構造の取得には超音波断層像を 用いており，断層像計測時に超音波プローブの空 


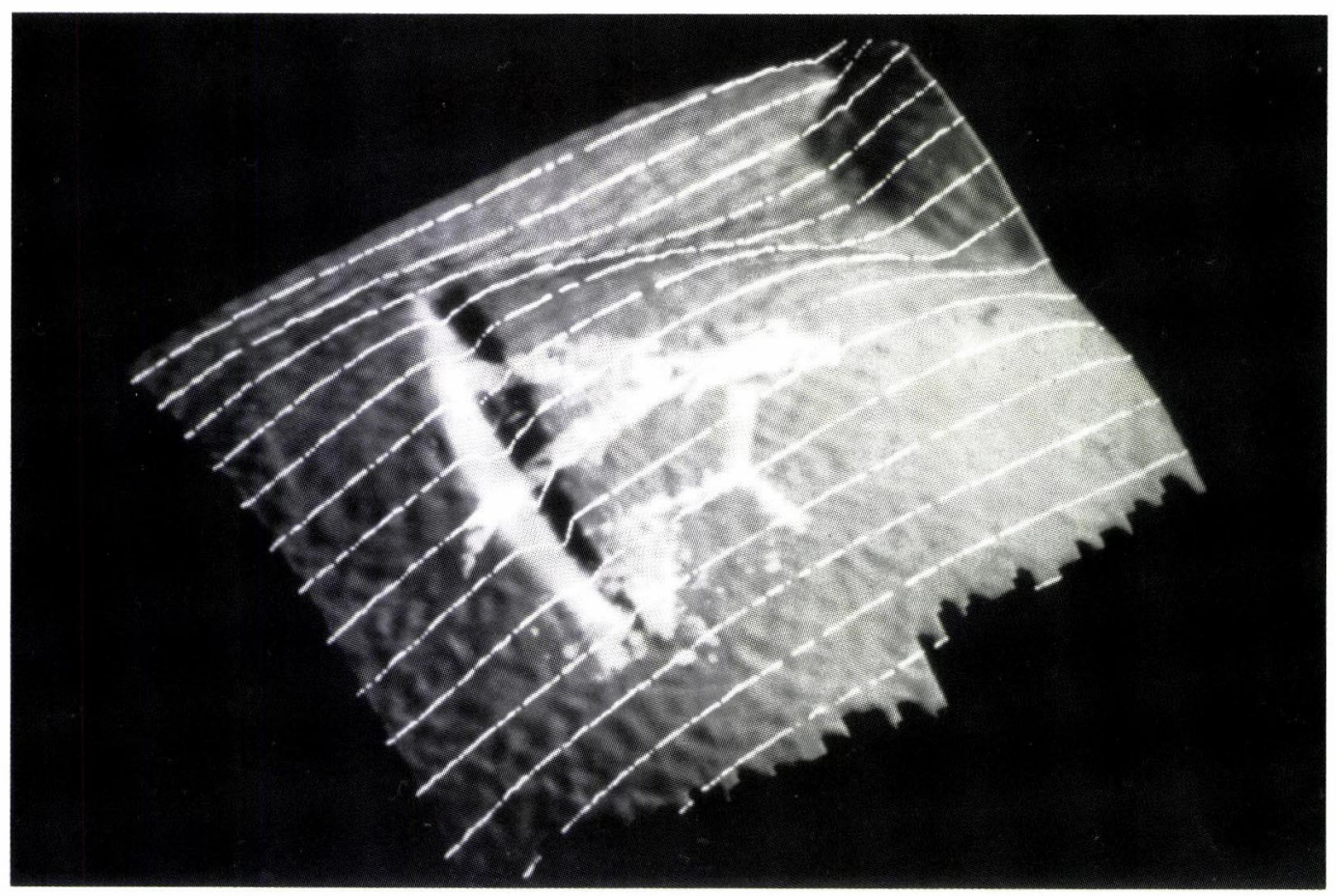

図 2. 試作 data fusion システムにより得られた摘出肝の表面形状と超音波断層像から再構 築した血管及び腫場の様子

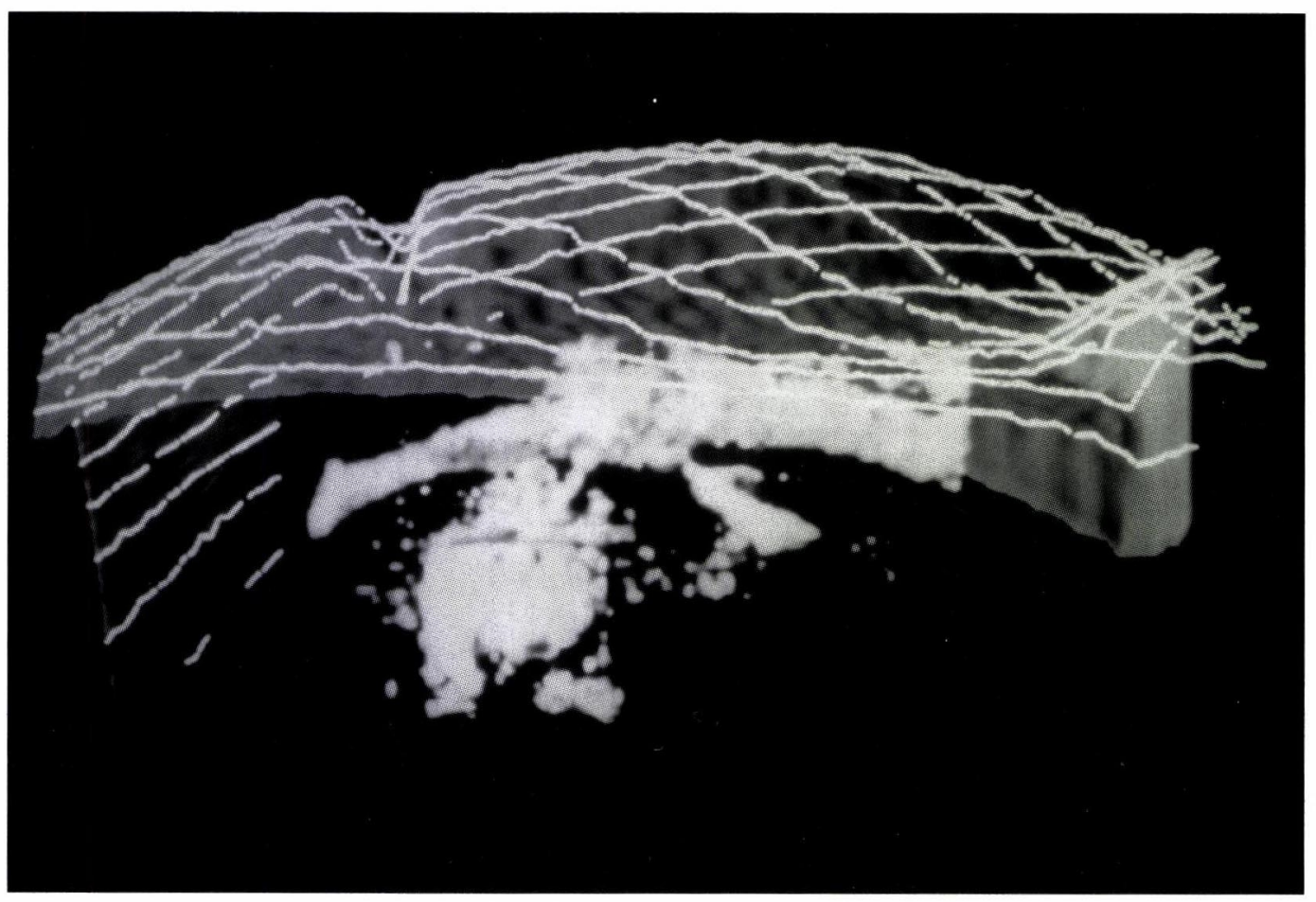

図 3.図2の視点を下方に変更したときの様子 
間的な位置を同時に記録して内部構造の三次元再 構築を行う。術野の表面形状については, 超音波 断層像から計測することは難しいため, レーザ ビームスキャナを用いて計測を行った。 これらの 内部構造および表面形状のデー夕は, 座標変換を 行って術場の座標系と一致させて合成し, 術者に 提示した。また提示の際, 術者の頭部位置を計測 して術者の視野と一致させた画像提示を行うた め, 透過型の HMD を用いることで実際の術野と その下にある三次元再構築された内部構造を同時 に見ることができる．図２は，このシステムを用 いた摘出肝での実験例である．図は摘出肝の表面 に切開を行った直後の切開部とその下にある血管 構造抢よび腫瘍の様子を示している，また，座標 変換を行って図 3 のように臓器内に視点を置くこ とにより，切開部とその下にある血管や腫瘍の距 離を随時確認することも可能である。このような 手術支援システムの実用化は, 切開を進めていく 際にその下にある内部構造を把握しながら作業を
進めていくという新しい手術の方法を可能にする ものと考える.

$$
N \text {. 手術シミュレーションシステム }
$$

VV. 1. 仮想手術 (virtual surgery) システム

手術シミュレーションとは, 手術前に想定され る術式をコンピュータ上で行うことである。この 際，デー夕を患者から取得し，VR 技術を用いる ことで仮想空間内でこれから行う手術を事前に試 行し, 患者毎の手術計画を立案することが可能に なる。ここでは例として, 臓器等の軟組織は柔ら かいものとして仮想空間上で扱い, 手術シミュ レーションができるvirtual surgery システ

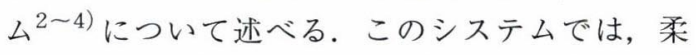
らかいものは使用者が触ると変形するとともに, force feedback 装置を使用者が装着し, メスや鉬 子などの手術器具を使って仮想空間上の患者の対 象部位の触感 (柔らかさ)を感じながら手術シミュ レーションを行うことができる. 触感は, 使用者

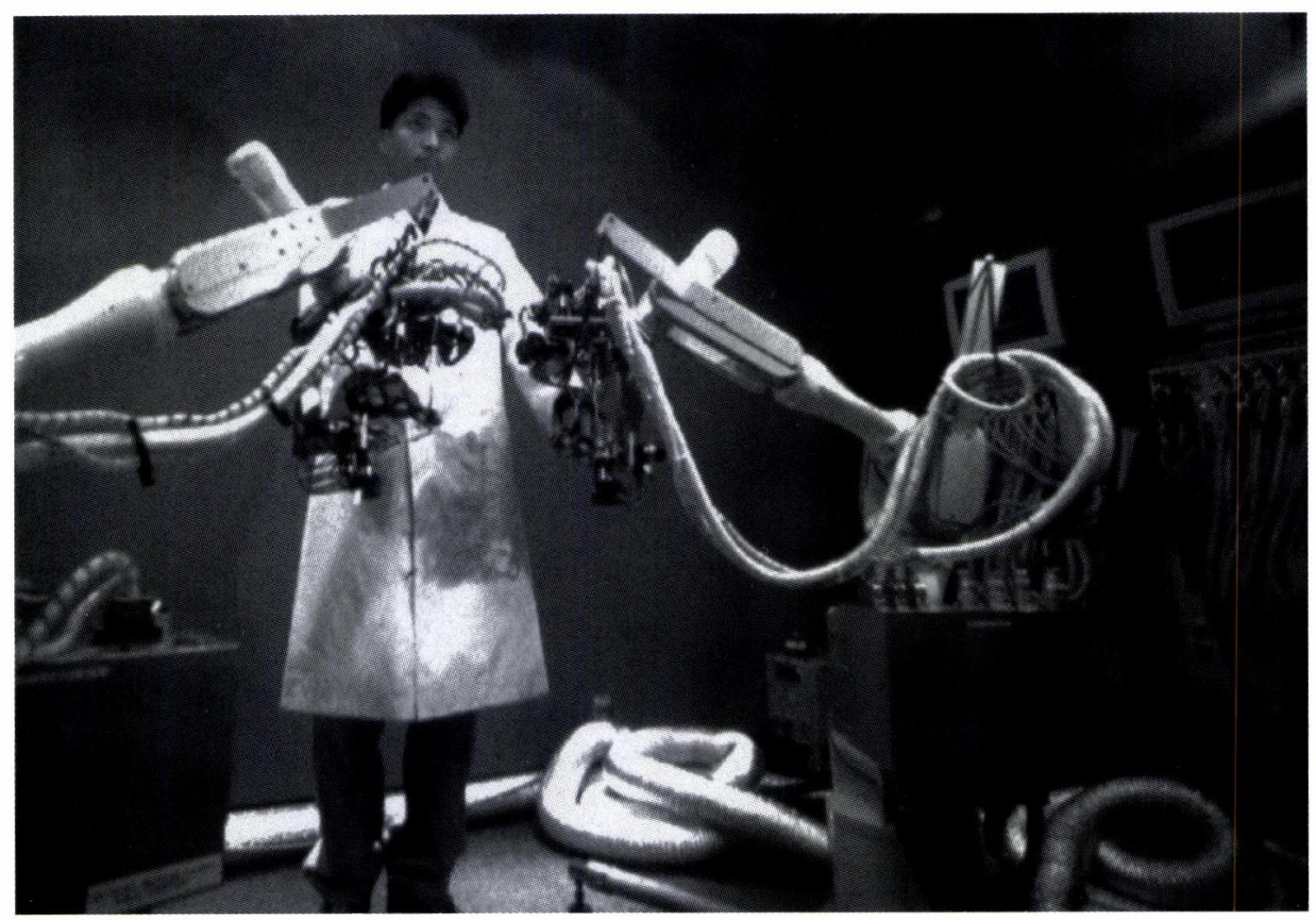

図 4. 仮想手術用 force feedback 装置使用時の様子 
が仮想空間内の対象部位に触れるとコンピュータ 上で刘象部位の変形処理を行い，その際に算出さ れた反力が force feedback 装置を通して使用者に 返ってくることで表現している。図 4 にforce feedback 装置を用いて仮想手術を行っている様 子を示す。図は，使用者が画像を見ながら force feedback 装置を用いて手術操作を行っている様 子である。図 5 は, 使用者が見ている術野の画像 を示す. 図は, 肝切除術の手術シミュレーション において, 電気メスによる切開を肝表面に対して 行っている様子である.体表や臓器等のデータは, 患者から取得したものを使用するため，先に述べ たような患者ごとに適した術式の決定が可能とな る。また，何度でも繰り返し試行できるため，複 雑な手技についても十分な試行を繰り返し，その 症例に慣れてから術場に臨むことができると考え られる。また，臨床での手術シミュレーションと してだけでなく, 手術の教育を医学生に体感させ ながら行えることもこのシステムのメリットの一 つであると考える。

\section{2. Tele-virtual surgery}

前項IV．1．で述べた手術シミュレーションは， コンピュータ上で行われるため, ネットワークを 利用することでどこからでもシミュレーションを 行えることも特徴の一つである。遠隔地間での tele-virtual surgery の例として，日本一ドイッ間 で行った実験のドイッ側の様子を図 6 に示す。こ
の実験では，デー夕，ビデオおよび音声信号の通 信用に ISDN $64 \mathrm{~K}$ のみの通信回線を用いて日本 一ドイッ間を結び，日本側にIV．1。で述べた両 手用の force feedback 装置, ドイツ側に片手用の force feedback 装置を設置して実験を行った. 1999年 3 月にこれらの装置を用いて, 慈恵医大と ボン大学医学部の外科医が, 共同で仮想空間上の 患者の触診やメ又等の手術器具を用いて手術対象 部位の感触を得ながら腹部での virtual surgery を行うことに成功した。

\section{V. 手術用データグローブ}

現在，バーチャルリアリティ技術を利用して， 上に述べたような data fusion や augmented reality などの様々な手術支援環境が提案されてる.

しかし執刀者が，手術中にこれら各種の情報を取 得し, 手術に反映させるためには, 術者以外の人々 による多数のサポートが必要となる。 そこで患者 に対し執刀を行いながら，様々な情報を提供する 手術支援環境を操作できるグローブ型インター フェイスの開発を行う必要があった。従来, コン ピュー夕機器などの操作はキーボードなどによっ て行われていたが, 今回開発したグローブ5)に よって, 手術をしながら HMD などの表示装置に 表示される仮想空間内の様々な情報を手の動きに よって自由に操作できるような環境を目指してい る.

このグローブによって操作する情報の種類とし

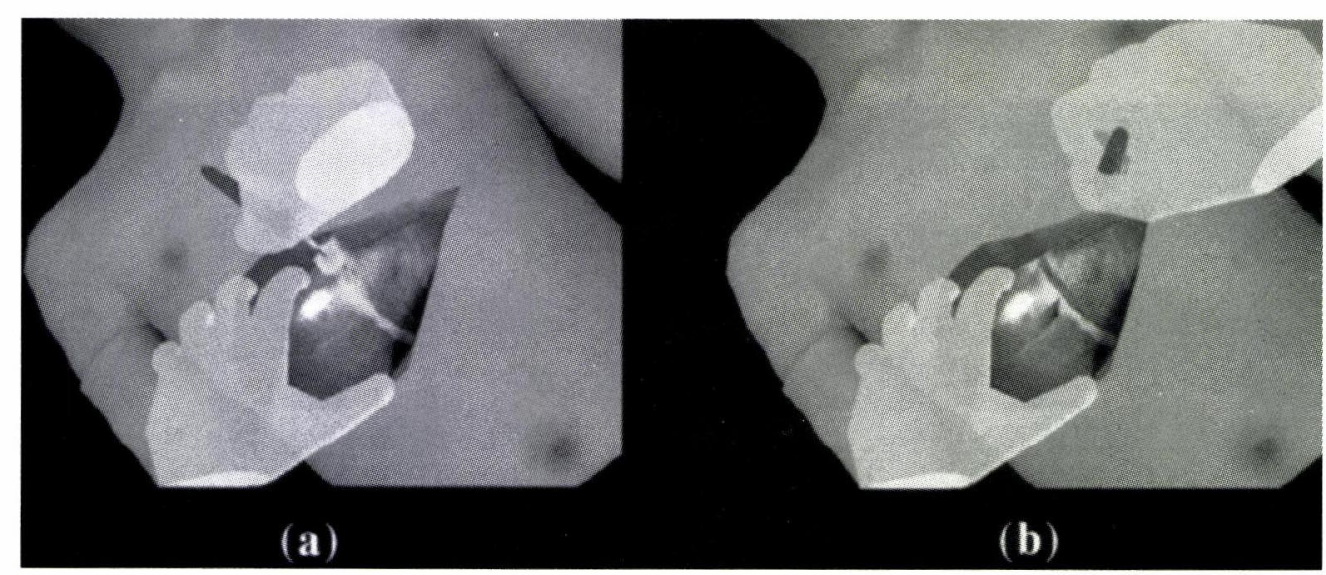

図 5. 仮想手術での電気メスによる切開の様子 


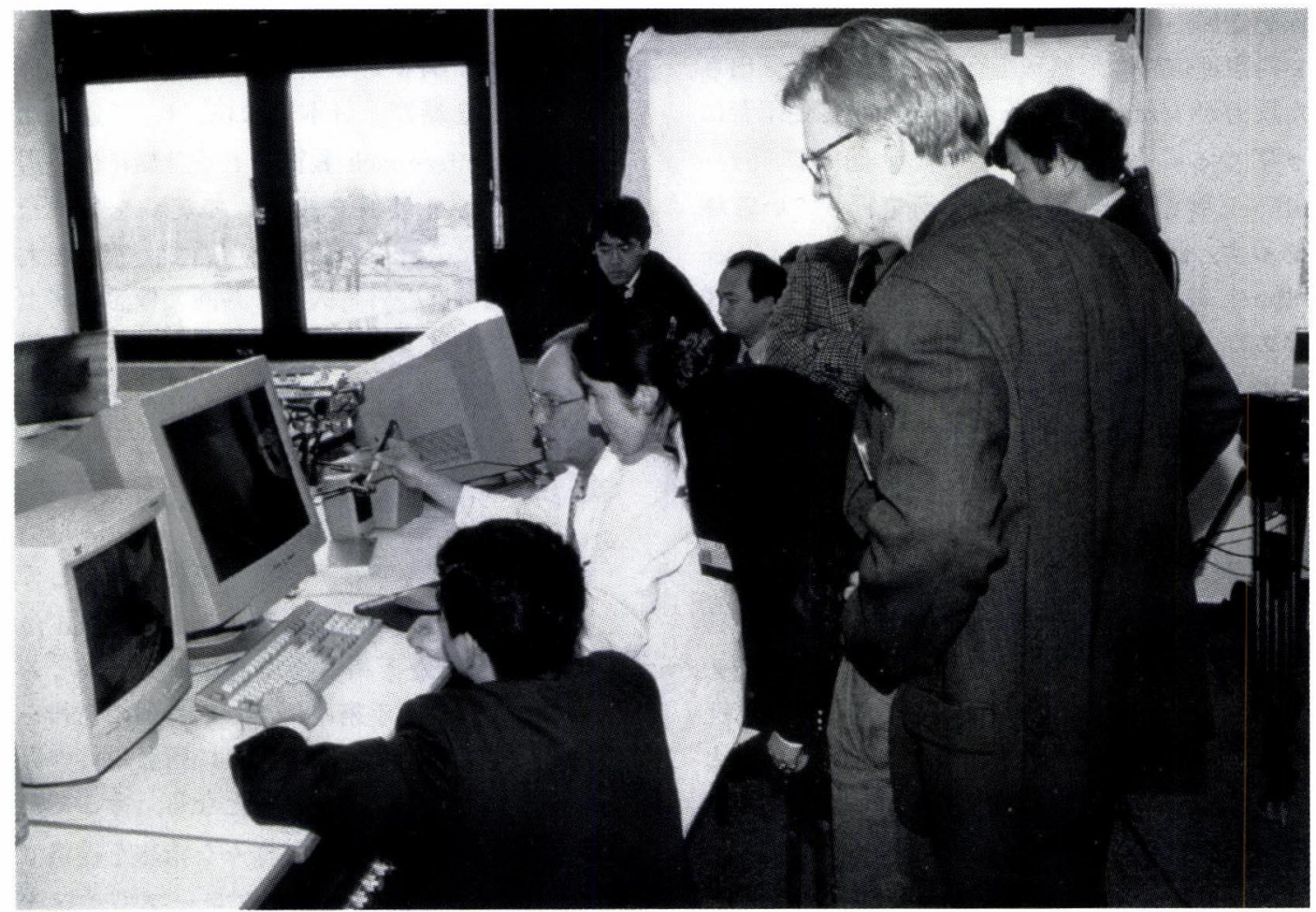

図 6. 日独間 tele-virtual surgery 実験の様子

ては，一次元情報として患者のカルテ，各種デー 夕ベース，心拍数などの数值情報といった文字情 報，心拍波形などの時系列情報は言うに及ばず, 二次元情報としての MRI などの画像情報を自由 に術者の視野内に提供することができる.さらに, リアルタイム三次元情報として data fusion に用 いられる患者患部の三次元再構築像を視野内に提
供して，内部を見ながら手術を行う際の情報をこ のグローブで操作することも可能である。手術環 境下での利用を考えたグローブによって，このよ うに特徴の違う様々な情報を，自由な手と指の動 作によって，より便利に取り扱えるような手術支 援環境への適用が考えられる，外装に手術用の手 袋を用い，装着した指の動きにしたがってコン

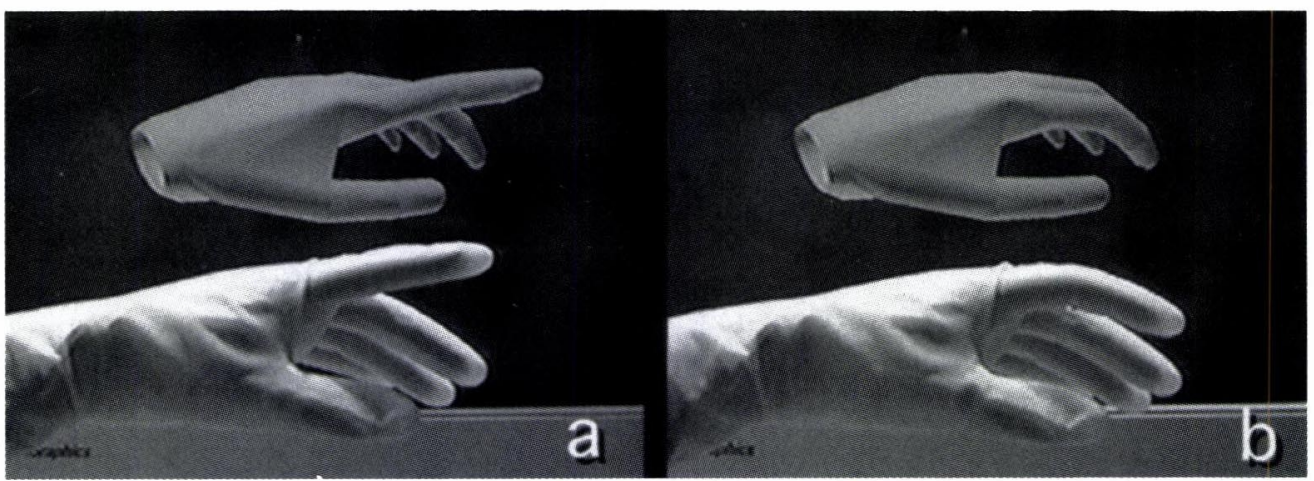

図 7.手術用データグローブとそれに連動して動作するモデルの様子 
ピュータ上のモデルが動作している様子を図 7 に 示す．このグローブ型インターフェイスを用いる ことで，実際の手術を行いながら，手術支援環境 を操作する, 手術と同じ状況でシミュレーション システムを使用する，手術時に装着する等の状況 で手術技法の記録に利用するなどの様々な利用法 を考えることができる．将来的には，様々な手術 支援システムとの融合が可能であると言える.

\section{V. を め}

従来の医用画像は, フィルムやディスプレイ上 の二次元画像での見る診断に使われているのみで あった。しかし、コンピュータやVR 技術の発 達によって, 本来データが持っている三次元構造 を視覚, 触覚等の五感を使って素早く, 的確に理 解し,インタラクティブに操作することが可能に なってきた.このことは, 人間が本来持っている 能力をさらに伸ばす，もしくは足りない部分を 補って様々な医療作業を行うことが可能になった といえる。しかし，上に述べてきた様々なシステ ムを臨床で利用するには, まだ解決すべき問題は 多い. 例えば, 医用画像の三次元再構築を行う際 にいつも問題となることでもあるが, X 線 CT や MRI などの医用画像から, 対象となる臟器や 血管, 腫瘍といった特定の軟組織をコンピュー夕 上で自動的に認識, 抽出し三次元画像化する技術 はまだ十分とはいえない.今後も医用画像の情報 はさらに高次元化し, 一回の計測情報量が著しく 大量になると考えられるため, 従事者の作業量の 削減, 診断の高速化のためにもこの領域の研究開 発が必要である。また, data fusion などで軟組 織(特に腹部臓器)を扱う場合, 術前に構築した対 象部位の三次元構造と術中の構造は, 姿勢や状況 の変化等によって一致しない場合が多い.このた め, 術中に使用するためには, 術中に得られる情 報を用いて両者を一致させる手法が必要となる. これが可能になれば, 広範囲の手術において内部
を見ながら手術する術式が一般化するであろう。 また, 現状のVR関連のインターフェイス機器 (HMD，データグローブ等) は，医療の現場が求 める条件を満たしたものは少ない.このようなイ ンターフェイスに求められる条件としては, 使用 者の動きを妨げず，手術環境下でも利用できるよ うな形態であることが求められ，このような医療 に特化したVR 周辺機器の開発が望まれる。ま た医療分野では， data fusionに代表されるよう に他の分野に比較して特に安全性と精度が求めら れていることも重要である，臨床でVR 技術が 常用されるようになるにはこれらのような問題を 解決する必要がある。しかしながら, 今後の多く の研究開発によりこれらの問題点が解消され, VRに関連する技術が現実化し, 診断, 治療, 医 学教育等, 医学の広い範囲で応用され, 今までに はない新しい医学を創っていくことになると考え る.

\section{参考文献}

1) N. Suzuki, A. Takatsu. Development of a computer assisted support system in the field of surgical operation with 3 -dimensional imaging technique, Simulation and computer-aided surgery. John Wiley \& Sons Co. ; pp. 183-9: 1994

2) N. Suzuki, A. Hattori, A. Takatsu. Medical virtual reality system for surgical planning and surgical support, J. Comput. Aided Surg., 1 (2) ; 54-59 : 1995.

3) N. Suzuki, A. Hattori, S. Kai, T. Ezumi, A. Takatsu. Surgical planning system for soft tissues using virtual reality. MMVR5, Eds : K.S. Morgan et al., IOS Press ; pp.159-163: 1997.

4) T. Ezumi, N. Suzuki, A. Takatsu, A. Uchiyama. Development of an elastic organ model for force feedback manipulation. World Congress On Medical Physics and Biomedical Engineering; 830 : 1997.

5) S. Oda, M. Kyoso, A. Uchiyama, A. Takatsu, N. Suzuki. Development of a glove-type interface to manipulate operation assist environment, Proceedings of 7th J. Comput. Aided Surg., pp.101-2: 1998. 